\title{
The Compatibility of "Guess What" Textbook Based on English Final Exam Framework 2018/2019
}

\author{
Andyna Rakhma Ilahi \\ STKIP PGRI Sidoarjo, Email: andienrachma@gmail.com
}

\begin{abstract}
This study is used descriptive qualitative because the researcher wants to understand the contexts. The researcher is focused on the analysis of "Guess What" textbook. There are 2 parts of this book; pupils' book and activity book. The students in this school only use the activity book to do the exercise while the teacher has both. In this study, the researcher took the data from the materials in the textbook to analyze whether this book compatible with the question indicators in English final exam framework or not. The result of this study tells that the compatibility is $62 \%$ and the incompatibility is $38 \%$ from the total questions 50 numbers, 30 numbers are multiple choice, 15 numbers are short answer and 5 essay questions. It can be concluded that this textbook is compatible with question indicators in English final exam framework 2018/2019.
\end{abstract}

Keywords: Guess What textbook, English final exam framework

\section{INTRODUCTION}

Textbook is the general learning media used in schools. Government also provides textbook to support teaching and learning in the class. According to Ferris and Hedgcock (2005: 125) textbooks are so effective in educational systems throughout the world. Textbooks provide the learning materials that appropriate with students' needs and also the teaching goals. Harmer (2007) also states that the most important aspect of textbook use for teachers is to engage students' interest with the content they are going to be dealing with. So that, textbook is the important media in teaching activity to reach the teaching goals.

In this era, there are many kinds of textbook for EFL students which are used in schools. Those textbooks are published by different publishers. Some of them are published by their own country or even from other countries. Grant (1987:118) inferred that "the perfect book does not exist". It means that every book has its weaknesses even though it published by famous publisher. So that, as a teacher, they should analyze books to know whether the book appropriate with students need or no.

Textbook analysis is a process of choosing textbook to use in teaching activity by considering students' need. The purpose of textbook analysis is to support teachers teaching activity and help teachers to gain good and useful insights into the nature of 
material (Cunningsworth: 1995). The goal of textbook analysis is to decide the best teaching media as a resource of EFL teaching.

To know the students' needs and teaching goals, government make a curriculum for every subject and it dragged down into syllabus and lesson plan. In elementary school, English subject included in local content or muatan lokal. And based on Muhammad Nuh, the Ind onesian Minister of Education and Culture, English subject is not the prime subject in elementary school, schools are free to put English into subjects or not. So, English curriculum is not available for elementary school.

To solve the problem above, the schools which put English as subject, they join UASDA which held by government. UASDA is the final test for English in elementary school and it will be done by sixth grade student beside the national tests named USBN or Ujian Sekolah Berbasis Nasional. Other subject tested for USBN non utama are social studies (PKn), (IPS), and local content curriculum like Javanese and Arabic language. For reaching the same goals between government and teachers in USBN test, the government shares the English final exam framework for every subject. Usually, the USBN materials contain of fourth, fifth, and sixth grade's materials to test students' understandings toward them.

Based on background of study above, problem that discussed in this research is: to what extent are the materials in the "Guess What" textbook compatible with the question indicators in English final exam framework? With the objective to know the extent of materials in the "Guess What" textbook compatible with the question indicators in English final exam framework.

\section{METHOD}

The researcher used descriptive qualitative because the researcher wants to understand the contexts (Creswell, 2007:40). In other words, the researcher analyzed, interpret and report the data in the "Guess What" textbook whether the materials compatible with the question indicator of sixth grade in English final exam framework or not. And the researcher chose document analysis which is one of many kinds of descriptive qualitative method.

Document analysis is a method that is widely applied for written or visual data with the purpose of identifying specific characteristic of materials that are going to be analyzed 
in general form of textbook, newspaper or any other host of documents (Ary, 2010). In short, document analysis is the method which analyze the document or written data.

In this study, the researcher used an English textbook as research object and analyze it by broking down the materials in the textbook then examined using observation checklist based on English final exam framework

Sutopo (2002: 49) states that source of data perhaps in the form of human beings and their social behavior, event, document, article, and so on. The source of data for this research is the English textbook published by Cambridge University Press. The textbook entitled "Guess What" has two kinds of book, the pupil book and the activity book. This book designed for young learners who learn English as second language.

Data is information on the phenomenon to be recorded (Klaus Krippendorf: 1981). The data of this study is the materials and exercises in the textbook "Guess What". The textbook contains on 9 chapters, starts from chapter 0 until chapter 8 and 103 pages. Every chapter has many exercises which train pupils' vocabularies, grammar, speaking, writing, listening and reading.

In this research, the data analysis technique done on some steps:

1. The researcher gained the data from the materials in the "Guess What" textbook based on specific materials.

2. Then the researcher did the observation using checklist instrument to know whether the materials in the English final exam framework contained in the "Guess What" textbook.

3. In observation stage, the researcher gave the short explanation about the relevance between materials in English final exam framework and the materials delivered from the textbook.

\section{FINDINGS AND DISCUSSION}

The Compatibility of Guess What Textbook Based on Question Indicators in English Final Exam Framework

The researcher in this study did the observation using observation checklist to know the compatibility between the Guess What textbook and the English final exam framework 2018-2019. The observation checklist used in this study was adapted from Devi Audina Pratama (2017). There are 31 question indicators that compatible with Guess What textbook while the rest 19 question indicators are not compatible with Guess What 
textbook. In percentage form, the compatibility of Guess What textbook toward English final exam framework is $62 \%$ and the incompatibility is $38 \%$. And from the percentage number, it can be shown on the graphic below.

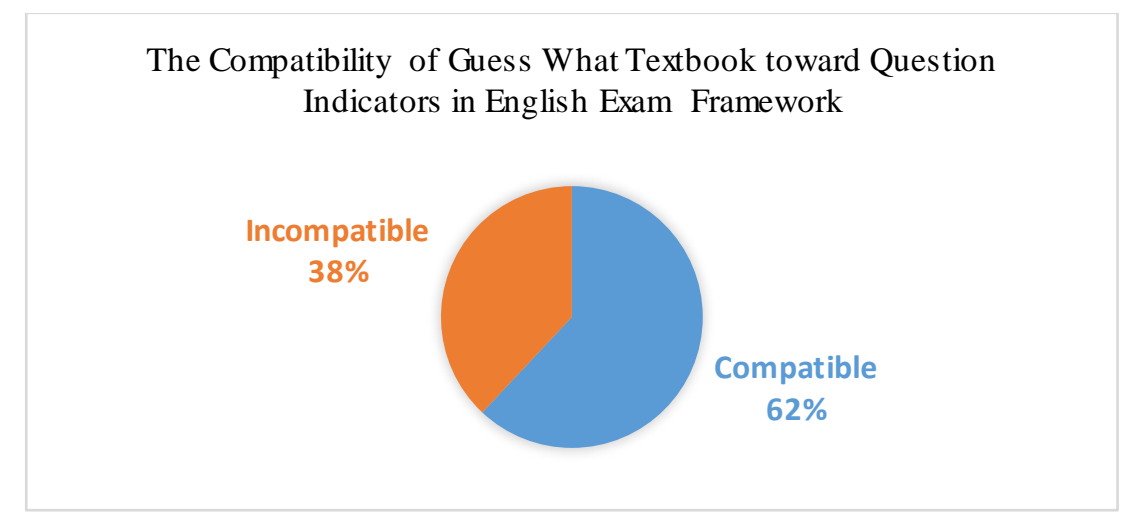

Figure. 1 The Compatibility of Guess What Textbook toward Question Indicators in English Exam Framework

And the researcher also verified the compatibility of textbook toward question indicators in English final exam framework in brief explanation. The explanations below grouped based on the textbook level, level 1 up to level 6.

a) Guess What Textbook level 1

This textbook designed for ESL young learners who started to study English in beginner level. In Indonesia, it used for first grade students of elementary school. This textbook consists of more interesting pictures than others and this might attract students interesting in learning English. There are some question indicators of English final exam framework found in this textbook level and most of them are the important basic knowledge. The first material found in the Guess What textbook level 1 is the WH questions. Almost all chapter contained of WH questions in grammar skill. The WH question used in this level are what, who, where and how. The yes and no questions using is, have, do and can also delivered in this level. The second material found in this level is modern game. This materials delivered in vocabularies version in chapter three "Toys". Games vocabularies delivered with interesting picture and makes learners easy to understand and remember. Thanking material also found in this chapter, it delivered in a comic version which contained of characters and also easy dialogue. This comic also has story value that persuade young learners 
to habituate thanking. The last materials in this level is found in chapter five, "My Body". In this chapter, parts of body and also their function delivered well. Part of body vocabularies are delivered in clear picture and the functions delivered in short video.

b) Guess What Textbook level 2

This textbook used for second grade students of elementary school. This second level textbook has four characters which may guide teachers and learners to study easily. And in this level, there is interesting chant and song every chapter based on the theme. Those activities are help learners to remember the material and also attract students' enthusiasm. The first material found in Guess What textbook level 2 is WH question. What and how are used in grammar skill of chapter "Hello Again!", third chapter "Clothes", fourth chapter "Rooms", and eighth chapter "On the Farm". The second material found in this level is transportation in chapter one "Transport". The transportation vocabularies delivered well with clear pictures. Short video about the types of transportation also delivered in this chapter to enlarge the learners' knowledge about transportation. The third materials about adjective to describe something also found in chapter two "Pets". In this chapter, learners invited to describes pets in simple way based on their physical appearance. The fourth material found about meal time introduced in fifth chapter "Meals". It introduced the meal time and also the appropriate food based on the meal time. The last material is modern games also found in chapter six, "Activities". The vocabularies in this chapter are related to the sport game and they are outdoor activities.

c) Guess What Textbook level 3

Guess What textbook level 3 deepen the four prime skills; listening, speaking, reading, and writing skills. Listening delivered in a simple worksheet by listening to the audio. Speaking delivered in a simple instruction to do conversation in pair based on instructions. Reading delivered in short passage and also questions to check their comprehension toward text. And writing email or letter is the example of writing skill task. The first materials found in this level is WH question. Almost all chapter delivered WH question in grammar skill. When, what, where, which, and whose are delivered well in this level. The second material about date found in "Welcome" chapter. Months of the year are introduced in this chapter. Days also delivered in 
chapter three in this textbook. The third material found in this textbook is about school activity. In chapter three, a brief explanation about different activities in each day are delivered well. The fourth material about telling time found in chapter 4, "My Day". The word "half past" and "o'clock" to tell the time only used in this chapter. This chapter also shows the picture and also the activities learners usually do at that time. The last material found in this level is market in chapter 7 "At the Market". This chapter contains of vocabularies related to the things sell in the market and also the short dialogue in the market.

d) Guess What Textbook level 4

Guess What textbook level 4 designed for ESL young learners or in Indonesia is the same as fourth grade of elementary school. The first material found in this textbook level 4 is WH question. WH question learned in this level are how, what, and where. The second material found in this textbook is about personal character or describing person. This material learned in chapter "Welcome Back!". In this chapter, the materials focus on describing the physical appearance of person from the hair type and colour, skin tone, etc. The third material found in this textbook is about tourism object in chapter two "Around Town". The vocabulary tells about the public place in the town. The textbook also provides the clear picture for each vocabulary. The fourth material is about direction and location. It also delivered in chapter two. This material showed in dialogue version between two persons about asking direction. The last material found in this book is about weather. It found in chapter eight "Weather". The weather vocabularies also delivered well with clear pictures. And this material provided short video with the same topic to enlarge learners' knowled ge about this material.

e) Guess What Textbook level 5

Guess What textbook level 5 is more practical than levels before. There is extra text and also the short dialogue related to the grammar. It may train learners to be more active and practice their reading and speaking. The first material found in textbook level 5 is date in ordinal number. It found on chapter "Around the World" by eliciting students about the date of their birthday. The second material found is WH question. The WH questions used in this level are when, where, who, which, and why. Most of all WH questions in this level used in the past form. The third material 
found in this level textbook is about modern games. This material delivered in clear picture, brief description, and also short passage about modern games. The last material is about changing sentence based on time allocation. There are so many materials related to past form in this level, such as regular and irregular verb in past form and also WH question asking about activity in the past.

f) Guess What Textbook level 6

Level 6 is the last level of this textbook. In this level, there is an extra exercise of grammar so the learners will more understand with many exercises. The first material found in this level is about seasons and weather. This material delivered in chapter "Seasons and Weather" which delivered well with the clear picture and also description. The exercises in this material also elicit learners to think more about the characteristics of seasons and weather so they may have more knowledge about seasons and weather. The second material found in this level is changing sentences. This level has 3 simple form, simple present, simple past, and simple future. And each of them explained in simple way and with the interesting exercise. And the last material is WH question. WH questions in this level are what and who. There are only a few of this material found in level 6 because most of grammar skill are related to past tense and also yes or no questions. From the previous explanation, the researcher makes the graphic to know the materials compatibility among six textbook level.

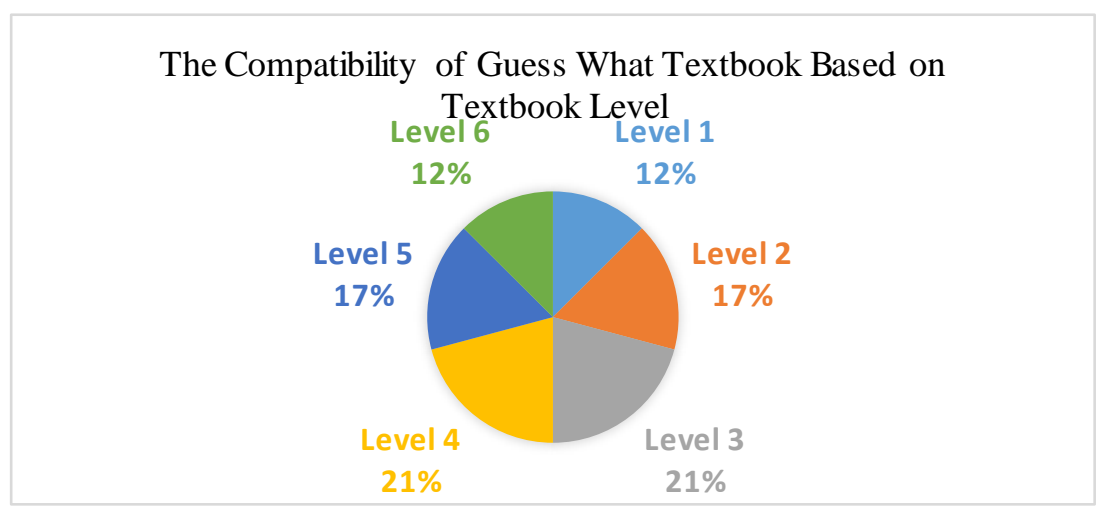

Figure 2. Percentage Compatibility on Textbook level

Based on graphic above, level 3 and 4 contained 21\% materials related to English final exam framework 2018/2019. While the level 1 and level 6 only contained $12 \%$ materials related to English final exam framework 2018/2019. 


\section{The Textbook Analysis}

The researcher did the research toward Guess What textbook from level 1 until level 6. In every chapter of the textbook has their skill parts they will focus on, they are a) vocabulary, this part consists of vocabularies related to the topics and it delivered with pictures and also the pronunciation. b) Grammar, this part contained of grammar in statement and questions form. This textbook also provided the simple passage or dialogue. c) Story, this story delivered in comic version with bubble dialogue. The story related with the topic and also provided the different story value every chapter. d) Skills, in this part is not four skills delivered together but only one until two skills formed in simple exercises and e) CLIL, CLIL is the abbreviation of Content and Language Integrated Learning. The materials will be connected to other subject to improve students' knowledge and this part delivered in short video. Most of materials connected to Science, Mathematics, Art, Geography, etc.

\section{The Advantages and Disadvantages of the Textbook}

This book has many advantages mentioned with experts in the theory above, they are: a) This textbook provides an available source of materials which very interesting. b) This textbook very useful in providing support for inexperienced teacher because this book has many helpful guidance and also interesting exercises. c) This textbook serves as a tool to motivate students and get stimulation of language learning. d) This textbook used as a framework for the learning and teaching process for both students and teachers. This textbook provides the framework, syllabus and also structure for a program. e) This textbook provides a variety of learning resource such as workbook, audio and also video. f) This textbook is efficient which save teacher's time. g) This textbook provides effective language models and input which support for teachers whose first language is not English.

h) This textbook can train teachers with their teaching methods. i) This textbook is visually appealing.

Beside the advantages, this book also has the disadvantages as mentioned with experts in the theory above, they are: a) This textbook may contain inauthentic language like the text, dialogue and other aspects. b) This textbook may not reflect students' needs since the textbook written for global market. c) This textbook may deskill teachers since textbook already has many role to facilitate students. d) This textbook is expensive since this book published by Cambridge University. e) This textbook may be old and outdated 
if they were not make any revision so the information in the textbook are not relevant because of the outdate news. f) The reading level of the textbook may too difficult. Sometimes the text were adapted from references without adjusting in students reading level.

Even though textbook has advantages and disadvantages, but textbook has an important role to support teaching and learning process. Thus teachers must be smart in selecting appropriate textbook that compatible with students need.

After the researcher did the research toward Guess What textbook and English final exam using observation checklist, the researcher got some important points. This textbook is compatible with question indicators in English final exam framework 2018/2019. The compatibility is $62 \%$ and the data gained from Guess What textbook level 1 to 6 . And all textbooks contained of materials in question indicators.

The researcher claimed that this textbook has higher level than the textbook in Indonesia even this textbook designed for EFL young learners. The question indicators in English exam framework are the materials from fourth grade, fifth grade and sixth grade but the researcher found the materials delivered in the first level in Guess What textbook. And the researcher found the materials were delivered in easy way since there are so many pictures and also interesting exercises.

The researcher argued that this textbook is very appropriate with the framework and the learners will not face the difficulties if the book used by learners from their first year. But unfortunately, the school researched by the researcher still use this textbook for three years.

\section{CONCLUSION}

Based on the research findings, this textbook is compatible with question indicators in English final exam framework 2018/2019. The compatibility is $62 \%$ and the incompatibility is $38 \%$ from the total questions 50 numbers, 30 numbers are multiple choice, 15 numbers are short answer and 5 essay questions. The data gained from Guess What textbook level 1 to 6 which published from Cambridge University Press. This book designed for ESL young learners.

The researcher claimed that this textbook has higher level than the textbook in Indonesia even this textbook designed for EFL young learners. The question indicators in 
English exam framework are the materials from fourth grade, fifth grade and sixth grade but the researcher found the materials delivered in the first level in Guess What textbook. And the researcher found the materials were delivered in easy way since there are so many pictures and also interesting exercises.

The researcher argued that this textbook is very appropriate with the framework and the learners will not face the difficulties if the book used by learners from their first year. But unfortunately, the school researched by the researcher still use this textbook for three years.

\section{REFERENCES}

Ary D, Jacobs, L. C. \& Razavieh, A. (2010). Introduction to Research in Education, (8th Edition). Belmont: Wad sworth.

Ary, J.C. Jacobs, L.C. \& Razavieh, A. (1982). Pengantar Penelitian Pendidikan. Translated by Arief Furchan. Surabaya: Usaha Nasional

Babbie, E. (2007). The Basics of Social Research. Cengage Learning.

Callahan. D. (1966). The Question of Public Dishonesty. Counseling and value. V. 10.

Cavanagh, S. (1997). Content Analysis: Concept, Methods and Applications.

Creswell, J. W. (2007). Qualitative Inquiry \& Research Design: Choosing Among Five Approaches, Second Edition. Lond on: Sage Publications Inc.

Cunningsworth, A. (1995). Choosing Your Coursebook. Oxford: Macmillan Heinemann.

Ferris, D.R. \& Hedgcock, J.S. (2005). Teaching ESL composition: Purpose, process and practice. 2nd edition. Mahwah, NJ: Lawrence Erlbaum.

Fredericksen, J.R. and Collins, A. (1989). A systems approach to educational testing. Educational Researcher.

Grant, N. (1987). Making the Most of Your Textbook. New York \& London: Longman. Harmer, J. (2007). How to Teach English. London and New York: Longman Inc.

Heinle, T. (2000). Designing Language Courses: A Guide for Teachers, Canada: Kathleen Graves. 
Hsieh, H. F. \& Shannon, S. E. (2005). Three Approaches to Qualitative Content Analysis. Qualitative Health Research, Vol 15 no.9

Joubish, F. (2009). Educational Research Department of Education, Federal Urdu University, Karachi, Pakistan.

Krippendorf, K.(1981). Content Analysis (An Introduction to its Methodology). London: Sage Publication.

Krippendorff, K. (2004). Textbook Analysis an introduction to its methodology. Thousand Oaks, CA: Sage Publication Inc.

Longman. (1978). Longman Dictionary of Contemporary English. UK: Longman Group Ltd.

Meolong, L. J. (1991). Metode Penelitian Kualitatif. Bandung: Remaja Rosdakarya.

Mukundan, J., et al. (2011). Developing an English Language Textbook Evaluation Checklist. Contemporary Issues in Education Research - June Volume 4, Number 6.

Nazir, M. (2003). Metode Penelitian. Jakarta: Ghalia Indonesia.

O’Neill, J. R. (1982). Why use textbooks? ELT Journal. Vol. 36 No.2 (New York: Oxford University Press.

Pratama, D. A. (2017). An Analysis of Textbook Entitled "Pathway to English" Published by Erlangga at the First Semester of the $11^{\text {th }}$ Grade of Senior High School. UIN Raden Intan Lampung

Richards, J. C. (2001). Curriculum Development in Language Teaching. Cambridge: Cambridge University Press.

Sheldon, L.E. (1988). Evaluating ELT textbook and materials. ELT Journal, 42(4).

Smaldino, S. Russel, J. D. Heinich, R. Molenda, M. (2005). Instructional Technology and Media for Learning. Pearson Merrill Prentice Hall, Upper Saddle river, New Jersey Colomcus Ohio.

Sutopo, H. B. (2002). Metodologi Penelitian Kualitatif. Surakarta: UNS Press 
Titscher, S. Meyer, M. Wodak, R. Vetter, E. (2000). Methods of text and discourse analysis. SAGE

https://learnenglishkids.britishcouncil.org/helping-your-child/how-young-children-

learn-english-another-language (accessed on June 30 ${ }^{\text {th }}$ 2019)

https://republika.co.id/berita/pendidikan/eduaction/13/12/12/mxohs0-mendikbud-

bahasa-inggris-sd-muatan-lokal-tak-ada-instruksi-dihapus (accessed on July $4^{\text {th }} 2019$ ) 